\title{
IDN Times Strategy in Dealing with Online Media Competition
}

\author{
Farid Rusdi ${ }^{1 *}$ Imanuella Gerlani Ganesha Hutasoit ${ }^{2}$
}

\author{
${ }^{1}$ Faculty of Communication, Universitas Tarumanagara, Jakarta, Indonesia \\ *Corresponding author. Email: farid@fikom.untar.ac.id
}

\begin{abstract}
Online media is increasingly emerging in Indonesia. Easier content production and practical use are the reasons, one of which is the online media IDN Times. Despite being relatively young, the IDN Times has grown and developed so rapidly. IDN Times has succeeded in being ranked in the top 5 digital media in Indonesia according to Comscore, which is the standard data provider for measuring online audiences in Indonesia. This study aims to determine the IDN Times strategy in facing online media competition in Indonesia. The author uses the theoretical basis of the four management functions of planning, organizing, actuating, and controlling by George R. Terry and an analysis of strength, weakness, opportunity, and threat by Albert Humphrey. The author uses a qualitative approach with a case study method. The author uses the interview method with the IDN Times and documentation. To analyze and process the data that has been obtained, the author uses the Milles and Huberman method, namely data reduction, data presentation, and drawing conclusions. The author uses data validity techniques with source triangulation. The results of this study indicate the strategies implemented by IDN Times in terms of planning, organizing, actuating, and controlling. In terms of strength, weakness, opportunity, and threat. From these two aspects, the IDN Times strategy was formed and implemented to face online media competition.
\end{abstract}

\section{Keywords: Media, online media, management, analysis}

\section{INTRODUCTION}

The growth of online media in Indonesia is arguably increasing rapidly. Quoted from medcom.id [1], Head of the 2016-2019 Press Council Yosep Adi Prasetyo said there were around 43,300 online media outlets in Indonesia. This data was recorded in the Journal of the Press Council in November 2018.

The main factor of the large number of online media is that it is easy to organize online media without the need for a legal entity and production costs are much cheaper than conventional media. Media groups in Indonesia are also involved in creating their version of online media. Like kompas.com and tribunnews.com belonging to the Kompas Group, okezone.com which belonged to the MNC Group, and medcom.id which belonged to the Media Indonesia Group.

Some online media in Indonesia that exist without being part of a major media company are IDN Times, Brilio, and Hipwee. These three online media have groups, namely the target audience from millennials. IDN Times, Brilio, and Hipwee both adopt a participatory culture. Viewers can not only enjoy and comment on content but also produce content in online media. Futurologist Alvin Toffler [2] mentions this era as consumption, that is, people can become producers as well as consumers of information. IDN Times is an online media under the IDN Media group that was founded in 2014. IDN Times has the motto The
Voice of Millennial and Gen Z. News in IDN Times is packed with casual use of words but still prioritizes truth and speed of information. This is certainly in line with the characteristics and character of millennials and gen $\mathrm{Z}$ who want to be fast and practical. On the IDN Times website, there are various kinds of rubrics ranging from news, hype (entertainment), life (tips \& motivation), male, women, science, tech, food, regional, and others.

\subsection{Related Work}

The first previous research that became a reference was entitled Brilio.net News Presentation Strategy by Suseno and Rusdi [3] from Tarumanagara University. This research is contained in the journal Connection Vol.03 No. 01 of 2019. The theoretical basis used in this research is the theory by Mike Ward regarding news presentation and Lyons' theory regarding the millennial generation in reading news online. The method used in this research is qualitative. The results of this study indicate the Brilio.net strategy by writing and presenting news based on millennial characteristics. Brilio.net also held a meeting regarding news to be presented to millennials. Another strategy is to appoint young journalists to attract more millennial readers. The second research is a thesis entitled Tribunsolo.com News Strategy in Facing Online Media Competition by Syahida from the Surabaya State Islamic Institute in 2018 
[4]. The theoretical foundation used in this research is mass media, new media, news strategies, news competition in online media, and online journalism. The research method used is field research. This type of research is descriptive qualitative. The results of this study indicate that Tribunsolo.com uses 3 strategies. The selection of issues is emphasized on news that is important and interesting, refers to the $5 \mathrm{~W}+1 \mathrm{H}$ elements and inverted pyramid patterns when writing news and the last is media branding through headlines that are displayed dynamically from time to time and take advantage of social media.

The third study entitled Production Department Communication Strategies in Improving the Quality of Morning-Morning Programs on NET TV by Muhtadin Maghribi Arsha and Desy Misnawati from Bina Darma University. This research is contained in the journal Inovasi Vol.11 No.2 of 2017 [5].

The results show that the Production Department has the following strategies: Planning uses program planning strategies, program design, content, target audience, brainstorming, and head to head. Then, organizing (organizing) uses a strategy of increasing human resources through workshops, seminars, and sharing seasons held by HRD NET TV.

\section{BACKGROUND}

\subsection{POAC Theory}

The management function of POAC was stated by George R. Terry in his book entitled Management Principles in 1953. Managers perform four functions, namely planning, organizing, actuating, and controlling. The manager's job can be grouped into groups of tasks that have goals called management functions [5].

Management functions performed by managers are planning, organizing, actuating, and controlling. [5] Planning according to Terry and Rue (2008: 43) is the process of creating and determining goals and plans for a predetermined period. Goals mean the things that a company or organization wants to achieve. While the plan is a way or a way to achieve predetermined goals.

The definition of organizing [8] according to Terry and Rue (2008: 82) is a process to collect and organize all the necessary resources, including humans, so that work can be carried out so that goal can be achieved. In short, organizing is done by grouping various activities and group assignments within a company or organization. Terry and Rue (2008: 181) define actuating [5] as the process of bringing together the efforts or work of group members to complete and achieve goals both individually and in groups.

\subsection{SWOT Analysis Theory}

This theory was initiated by Albert Humphrey in 1960-1970 at the Stanford Research Institute. SWOT was brought up when he was conducting a study on company planning that had continually been unsuccessful. Rangkuti defines SWOT as the identification of various factors (strengths, weaknesses, opportunities, and threats) to determine the companies or organizational strategy [5].

The SWOT analysis factors are as follows. The first is the strength, Fatimah [6] defines strength as an advantage that is owned by a company. Strength can be easily identified if the company has something special. By knowing its strengths, a company can demonstrate the high quality it has and can have an impact on its progress. The company not only maintains the strength it has but increases the amount of its strength as well.

The second is weakness. Weaknesses can be in the form of facilities and infrastructure, quality or ability of employees, low consumer confidence, the mismatch between the company's products and the needs of consumers or the business world, etc [6]. Weakness is a natural thing. The company takes policies and determines strategies to reduce these weaknesses.

The third is the opportunity. Opportunity according to Fatimah [6] is a condition outside the company's area that is profitable and can advance the company. Opportunities can be found by comparing the company's internal analysis (strengths and weaknesses) with the company's internal analysis of competitors.

Then, threats is as conditions outside the company's area that can harm and hinder the company's running. Threats can become a barrier for a company to achieve its vision and mission if not addressed [6].

\section{METHODS}

The method used in this research is a case study. According to Yin [7] case studies can answer the problem formulation of why and how. The speakers in this study were Uni Lubis as the Editor in Chief of the IDN Times, Ernia Karina as the Manager of the IDN Times Community, and Lia Hutasoit as the IDN Times Reporter. Data collection techniques in this study were interviews and documentation. The interview used by the writer is semistructured. The author prepares interview guidelines and interviews are conducted with open-ended questions but there are still limitations. After obtaining the data, the writer used the data analysis technique of Miles and Huberman's model, namely data reduction, data presentation, and conclusion.

\section{FINDINGS AND DISCUSSION}

\subsection{POAC by IDN Times}

\subsubsection{Planning}

The Editor-in-Chief of IDN Times, Uni Lubis, mentioned the planning carried out by IDN Times, namely the annual 
meeting every October, the Objective Key Results every three months (quarterly), the editorial meeting every week, and the daily story outlook. There is also a rubric (internal) team meeting which is held every week. This was said by Lia Hutasoit as a reporter in the News rubric team, Metro Social \& Law section.

These things are done to determine goals and plans. One of them is the objective key result. Objectives contain the things that you want to achieve during the three months. Then the results key contains methods or strategies to achieve these objectives. The word objective is written in the book Basics of Management by Terry and Rue (2008: 29 ). The starting point of the management process is to determine organizational objectives or goals. Objectives are planned to provide direction and purpose to the organization or company [5]. Goals must be clearly defined and notified so they can be used to measure success or failure.

\subsubsection{Organizing}

Organizing carried out by IDN Times is an organizational structure that describes the position or position at IDN Times. Then, in the organizational structure, it is further divided into several rubric and hyperlocal teams.

IDN Times Community Manager Ernia Karina said that her team consists of 6 editors, 1 admin administrator, and several freelancers. Reporter Lia Hutasoit said that in the News rubric team, the Metro Social \& Law section, there were an editor and four reporters including himself. Each team is led by an editor and contains reporters and/or writers. The editor is in charge of his team. The reporter is in charge of covering and writing news.

This is following the notion of organizing according to Terry and Rue (2008: 82), namely the grouping process and each group has a leader to supervise its members [5]. Written in the book Fundamentals of Management by Terry and Rue (2008: 90) organizational structures or maps can help in identifying organizational levels, mentioning units from each level, and determining titles [5].

\subsubsection{Actuating}

Actuating that is carried out in coordination by the Chief Editor and Deputy Chief Editor to the editors. The editor is then responsible for managing his rubric team. As Chief Editor, Uni Lubis said that he made editorial notes every week which were conveyed through editorial meetings. The editorial notes contain matters that need attention for one week.

Ernia Karina as the manager said that team coordination was mostly done online through Google Meet and the WhatsApp group, especially during the COVID-19 pandemic. Briefing according to Terry and Rue (2008: 181 ) is to unite members' efforts or jobs to fulfill individual or group goals [5]. Uni Lubis as the Chief Editor applies its leadership, one of which is through its weekly editorial notes. Editors who are equivalent to mid managerial apply their leadership by directing and managing their rubric team.

\subsubsection{Controlling}

Controlling is done through meetings held and WhatsApp groups. Supervision is carried out anytime and anywhere. The Lubis Union said that supervision had taken place since the meetings were held. However, evaluation occurs at any time in the WhatsApp group called Hot Issue. This is following the meaning of supervision according to Stephen Robein (in Syafie, 2011), namely the process of ensuring the course of work by following every activity development. This process runs during planning, organizing, and implementing

Regarding the article, Ernia said that the editor mustensure that the articles written by the community writers are following the terms and conditions to be published in the IDN Times. He added that the editor was assisted by a plagiarism and typo check tool in selecting incoming articles. There is also a QC (quality check) editor who helps oversee articles published by IDN Times.

Lia Hutasoit as a reporter said that the editor gave evaluations and suggestions regarding the reporter's performance and work. He also added that the evaluation in his team continued to follow the news.

\subsection{SWOT by IDN Times}

\subsubsection{Strength}

In the SWOT Analysis Technique book [6], strength have an understanding of the advantages of a company or organization. The company or organization must also maintain the strength it has to remain an added value compared to its competitors. Uni Lubis mentioned the strength or strength of IDN Times, namely positioning or firm target readers, namely millennial and gen $\mathrm{Z}$, then the position of the company that is independent and not tied to interests, the format of the listicle article which contains subtitles or points, then the IDN Times team, who are on average 27 years old (millennial) so they can relate to readers and the community writers who contributed to producing articles.

As a manager, Ernia Karina mentions other strengths, namely editors and community writers interacting directly so that relationships are established, IDN Times provides rewards in the form of points (can be exchanged for money) to community writers whose articles are successfully published, an orderly and transparent system, and often include community writers. at various events held by IDN Times. 


\subsubsection{Weakness}

Weakness is the opposite of strength. Quoted from the book SWOT Analysis Techniques [6] can include advice and infrastructure, employee capabilities, quality, company product results, and others. Weaknesses are a natural thing and can even be advantages that are not owned by other companies or organizations.

The weakness that IDN Times has according to Uni Lubis is the millennial team because they still lack experience so they need more guidance and direction. Still related to this, the number of IDN Times teams which is relatively small is also a weakness. However, the small number of teams makes IDN Times not wasteful in terms of costs, even Lubis Union said that currently, it is still conducting recruitment. He added that the IDN Times editor must also be stricter in selecting articles.

Ernia said that the editors at the IDN Times Community have not been able to handle all submitted articles because of the high interest. Innovations for the IDN Times Community are also needed in the future because he thinks it is still stagnant for now. Lia said the weakness for now is the limited space for employees due to office policies related to the COVID-19 pandemic. Employees must ask permission and inform them if they want to travel. However, he feels that this policy is IDN Times' way of protecting the health of its employees.

\subsubsection{Opportunity}

Opportunities have the meaning as conditions that are beneficial and can advance a company or organization [6]. The opportunity that IDN Times can achieve is the millennial population that is spread throughout Indonesia. Uni Lubis explained that the millennial population is the target audience for IDN Times readers.

Also, he said that another opportunity is to develop hyperlocal areas in Indonesia to raise and cover local events or events. Currently, there are IDN Times hyperlocal in 12 provinces of Indonesia. As the manager of IDN Times Community, Ernia said that the opportunity that could be achieved was to become a writing forum for people with various interests and hobbies. Lia said that the opportunity for IDN Times in the future is to hold interesting events, especially those that millennials like.

\subsubsection{Threat}

Threats or threats are external conditions that can disturb and hinder a company or organization [6]. According to the Lubis Union, two threats could occur, namely, if IDN Times employees do not protect themselves by understanding and undergoing the Journalistic Code of Ethics and the Information and Electronic Law (ITE Law) and the production of unprofessional content. Ernia said that mistakes made by community writers and/or writers regarding articles can also threaten IDN Times. Lia said that the current IDN Times threat is the increasing number of online media competitors.

\subsection{Best Strategy to dealing with online media competition}

\subsubsection{Listicle format}

Listicle article format contains sub-headings or points, pictures, and descriptions or explanations. This format makes it easy for reporters or writers to convey messages or information through articles. Readers can more easily understand the contents of the article.

\subsubsection{Photo article}

One type of article that is often written by IDN Times reporters is photo articles. Unlike the usual listicle articles, photo articles only contain subtitles and photos. The explanation has been written in the subtitles so that it is shorter but still solid.

\subsubsection{Breaking news}

IDN Times actively uploads content on Instagram (@idntimes) ranging from articles, infographics, IGTV, live Instagram, and others. Uni Lubis said that when breaking news occurs, Instagram will be the first social media used by IDN Times to publish news.

\subsubsection{Community writers}

Ernia Karina said that IDN Times took a personal approach to the community writer. IDN Times Community as the party responsible for community writers has many WhatsApp groups that contain community writers from various regions. This is so that editors and community writers can get to know each other and be able to discuss and share knowledge.

\section{CONCLUSION}

In the planning process, IDN Times conducts annual meetings, determines the objective key results every three months, weekly editorial meetings, weekly internal team meetings, and daily coverage plans (story outlook). Then, in the organizing process, there is an organizational structure that is further divided into several rubric teams. The implementation is carried out, namely the chief editor and deputy editor in chief coordinating the editor. Then, the editor takes responsibility and directs his rubric 
team. Team coordination is done through meetings and WhatsApp groups. Supervision is carried out, namely through meetings and WhatsApp groups which are useful for overseeing all activities. Editors supervise the submitted articles and must comply with the terms and conditions to be published in IDN Times.

The IDN Times SWOT analysis in terms of strength is the positioning of millennial and gen $\mathrm{Z}$ readers, the position of independent and unaffiliated companies, the millennial IDN Times team, and the presence of community writers, and the format of articles in the form of a listicle (points). Meanwhile, in terms of weaknesses, namely the millennial IDN Times team due to inexperience and small numbers, quality is still weak, editors have not been able to handle all incoming articles and must be tighter, there is limited space for employees, and more innovation is needed. against the IDN Times Community. Opportunities that can be achieved are the millennial population spread across Indonesia who are targeted by IDN Times readers, developing hyperlocals in Indonesian regions, becoming a writing platform, and holding various interesting events. Threats that can occur are if IDN Times employees do not protect themselves by understanding and following the Journalistic Code of Ethics and the Information and Electronic Law (ITE Law), the production of unprofessional content, and the number of competitors or other online media.

Of the various strategies implemented, there are four of the best IDN Times strategies, namely the format of the listicle articles, photo articles, content on Instagram, and the relationship between.

\section{REFERENCES}

[1] A. Setiawan, "Media Online Perlu Berbenah Diri." Medcom.id, 2020,

[2] H. Margianto, and A. Syaefullah. Media Online: Pembaca, Laba, dan Etika. Jakarta: Aliansi Jurnalis Independen, 2012.

[3] A. Suseno, dan F. Rusdi. Strategi Penyajian Berita Brilio.net. Jurnal Koneksi, vol.3, 2019, pp:182. http://dx.doi.org/10.24912/kn.v3i1.6202

[4] A. K. Syahida, Strategi pemberitaan Tribunsolo.com dalam menghadapi persaingan media online. Skripsi. Fakultas Ushuluddin dan Dakwah Institut Islam Negeri. Surakarta. 2018.

[5] G. Terry, and L. W. Rue. Dasar-dasar Manajemen. Jakarta: Bumi Aksara.

[6] F. N. D. Fatimah, Teknik Analisis SWOT. Yogyakarta: Anak Hebat Indonesia, 2020.
[7] R. K. Yin, Studi Kasus, Desain dan Metode, Raja Grafindo. 2010 